\title{
Urban Commons for the Edible City-First Insights for Future Sustainable Urban Food Systems from Berlin, Germany
}

\author{
Nadine Scharf ${ }^{1}$, Thomas Wachtel ${ }^{2}$, Suhana E. Reddy ${ }^{2}$ and Ina Säumel ${ }^{2,3, *(1)}$ \\ 1 Lokale Agenda 21 für Dresden e.V., Schützengasse 18, 01067 Dresden, Germany; nadine.scharf@posteo.de \\ 2 Integrative Research Institute THESys Transformation of Human-Environment-Systems, \\ Humboldt-Universität zu Berlin, Unter den Linden 6, 10099 Berlin, Germany; \\ thomas.wachtel@hu-berlin.de (T.W.); suhana.reddy@hu-berlin.de (S.E.R.) \\ 3 Institute of Agricultural and Horticultural Sciences, Faculty of Life Sciences, \\ Humboldt-Universität zu Berlin, Invalidenstr. 42, 10099 Berlin, Germany \\ * Correspondence: ina.saeumel@hu-berlin.de or ina.saeumel@tu-berlin.de
}

Received: 29 December 2018; Accepted: 7 February 2019; Published: 14 February 2019

check for updates

\begin{abstract}
Urban planning is facing multi-layered challenges to manage the transformation towards a more sustainable and inclusive society. The recently evolved concept of an "urban commons" responds to the crucial need to re-situate residents as key actors. Urban food commons summarize all initiatives that are food-related (e.g., cultivation, harvest, and distribution), aiming at a visualization and utilization of value chains and the commons-based linkage between them. We explored first insights of food commons in Berlin based on semi-structured, in-depth interviews. Urban food commons strengthen identification, participation, self-organization, and social resilience, are steered by bottom-up processes, and can be a powerful tool for a transformation towards urban sustainability. However, a viable political integration of existing initiatives lacks due to structural implementation problems. Respondents recommend a pooling of all initiatives in a strong network and a mediation interface to coordinate between food commons and city administration and politics. A combined approach of commons and edible cities will be helpful for the development of future prove food systems.
\end{abstract}

Keywords: citizens engagement; cross-sectoral coordination; co-creation; sustainable urban development; urban agriculture; urban farming; urban gardening; urban transformation

\section{Introduction}

Due to ongoing urbanization processes, city dwellers are facing challenges such as pollution-related health risks, worsening income equality, social isolation, and scarcity of resources and space. Environmental injustice increases and the ecological footprint of cities exceeds the city's area often of a manifold, unless consumption patterns and supply chains are complex and include large food miles [1]. Yet, nowhere is the potential for change greater than in cities that harbor a large creative economy and a high diversity of drivers and provide niche developments and economies of scale. Pooling know-how, innovation, and resources, cities are the key drivers of systemic changes to meet global challenges [1,2]. There is growing awareness that prioritizing economic growth is not a solution for these multiple crises. Rather, cities have to be developed more sustainably. All actors must undergo significant changes such as the adaptation of governance to changing socio-economic dynamics [3]. Moreover, cities are not isolated entities, but they are globally interconnected and can consequently be catalysts for change at wider scales [4]. 
Urban sustainability problems are not necessarily intrinsic characteristics of urbanization, but can rather be considered as results of poor governance and planning [5]. Cities have already demonstrated successful pilot projects for sustainable solutions, integrating different perspectives, knowledge, and expertise and promoting active collaboration and experimentation with different approaches. Sustainable urban transformation integrates holistic, systems-based, integrative approaches [6]. Local communities can enhance participation and co-creation while governance and political streams thoroughly change and merge together with innovative business models in a transdisciplinary manner to exploit all potentials of sustainable and inclusive land use modes.

It is important to situate residents, not markets, technologies, or governments, as the key actors in developing sustainable and resilient cities. The feeling of dispossession and exclusion of citizens and of the claim for participation and a voice in decision making processes is increasing [7], and consequently people claim for the "Right to the City," which the philosopher Henri Lefebvre called the right for urban life quality and participation in urban life.

The research landscape has devoted a substantial amount of attention to the concept of "urban commons," because it has been evaluated as a viable and effective way of strengthening democratic bottom-up processes at a time when people feel increasingly powerless [2]. A commons is a self-organized system by which communities manage resources without reliance on the market or state [8-10]. Traditionally, commons are connected to rural common goods such as pastures, forests, or seashores and are therefore associated with the idea of social dilemmas and the danger of being misused and exploited [11]. The most important component is the relationship between a resource and its users, which is " $[. .$.$] embodied in the user-managed governance arrangements that regulate$ access" [2]. In this sense, the concept of the urban commons falls on a fertile ground prepared by numerous initiatives, associations, and administrative-political developments and reorganizations that currently address urban farming.

There is no "blueprint" by which urban commons function, but design principles support long-term existence [7,12]. Identification of boundaries of urban commons is crucial (i.e., user groups, characteristics of the shared resource, and who "the others" are; see [7]). Commons are a decentralized and local approach and thus are postulated as a credible alternative to non-transparent approaches of the globalized market. Thus, different platforms such as the "Commons Institute" and the "Commons Network" are gathering and producing knowledge around (urban) commons and connecting different actors $[13,14]$.

An urban commons is hypothesized to have high potential for catalyzing democratic and participatory dynamics in cities [3,10,15-17]. Nevertheless, the question arises as to whether these potentials really can be implemented for a viable sustainable urban development under the given political and social framework. Dealing with the conflicts of involved parties in an adequate way and being recognized from external authorities, in this case municipal government or administration, is crucial for the "survival" of urban commons [7]. Urban commons are facing the challenge of reacting to boundary negotiations, a largely diverse user community and the large-scale and multi-scalar constitution of the commons [9].

The participative principles of urban commons already facilitate citizen's engagement in numerous urban farming initiatives worldwide. The co-creation of urban landscapes for food production is a major step towards more sustainable, livable, and healthier cities. A multitude of initiatives around the world, however fragmented, are prospering from the bottom up, forming a global movement of "edible cities." The edible city approach has been arousing a substantial amount of scientific attention and is increasingly being implemented in cities around the world. The term was coined in the city of Todmorden and is linked to so-called "continuously productive urban landscapes" vision [18]. Here, food production becomes an integral part of a city and ubiquitous aspect of the urban matrix [19]. Their products, activities, and services—the edible city solutions (ECSs)—empower local communities to overcome social problems by their inclusive and participatory dynamics and to create new, green businesses and jobs, thereby generating local economic growth and fostering 
social cohesion. Compared to traditional nature-based solutions (NBSs) such as parks and forests, ECSs are going a step further by deepening the social dimension of NBSs. Initiatives based on edible urban green space directly and lastingly involve citizens in social processes, ranging from co-design to co-implementation and long-term co-management of evolving edible green spaces. ECSs invite citizens to co-create sustainable development pathways for their society and proactively change urban environments to their own benefit and thus induces a paradigm shift towards a more connected urban lifestyle [20].

Therefore, the main objective of this study is to obtain first insights into the specific value of urban commons for a sustainable development of urban food systems in the edible city. We aim to answer the following questions: What value is attributed to food commons for a sustainable urban development in Berlin? How are food commons related to the current practice of city administration and politics in Berlin? Do actors have recommendations regarding the further development of food commons?

\section{Materials and Methods}

Based on an existing definition of an urban commons [10], we define an urban food commons as a shared immaterial or material resource in urban spaces that is food-related, which is co-owned and/or co-governed by its users and/or communities according to their own rules and norms. The community sustains, builds up, and uses the food resources via growing, distributing, processing, storing, gathering, monitoring, or knowledge-generating.

As research on urban food commons is lacking, we here use the explorative and non-quantitative method of problem-centered, qualitative interviews to provide first insights of the urban food commons in Berlin. Nine interviewees were selected, aiming at maximum heterogeneity in their relation to food commons (Figure 1). Since the theoretical sampling of qualitative interviews is always linked to the respective setting, the rather novel topic does not allow for a larger number at the moment and theoretical saturation was quickly reached. More quantitative explorations on urban food commons are pending.

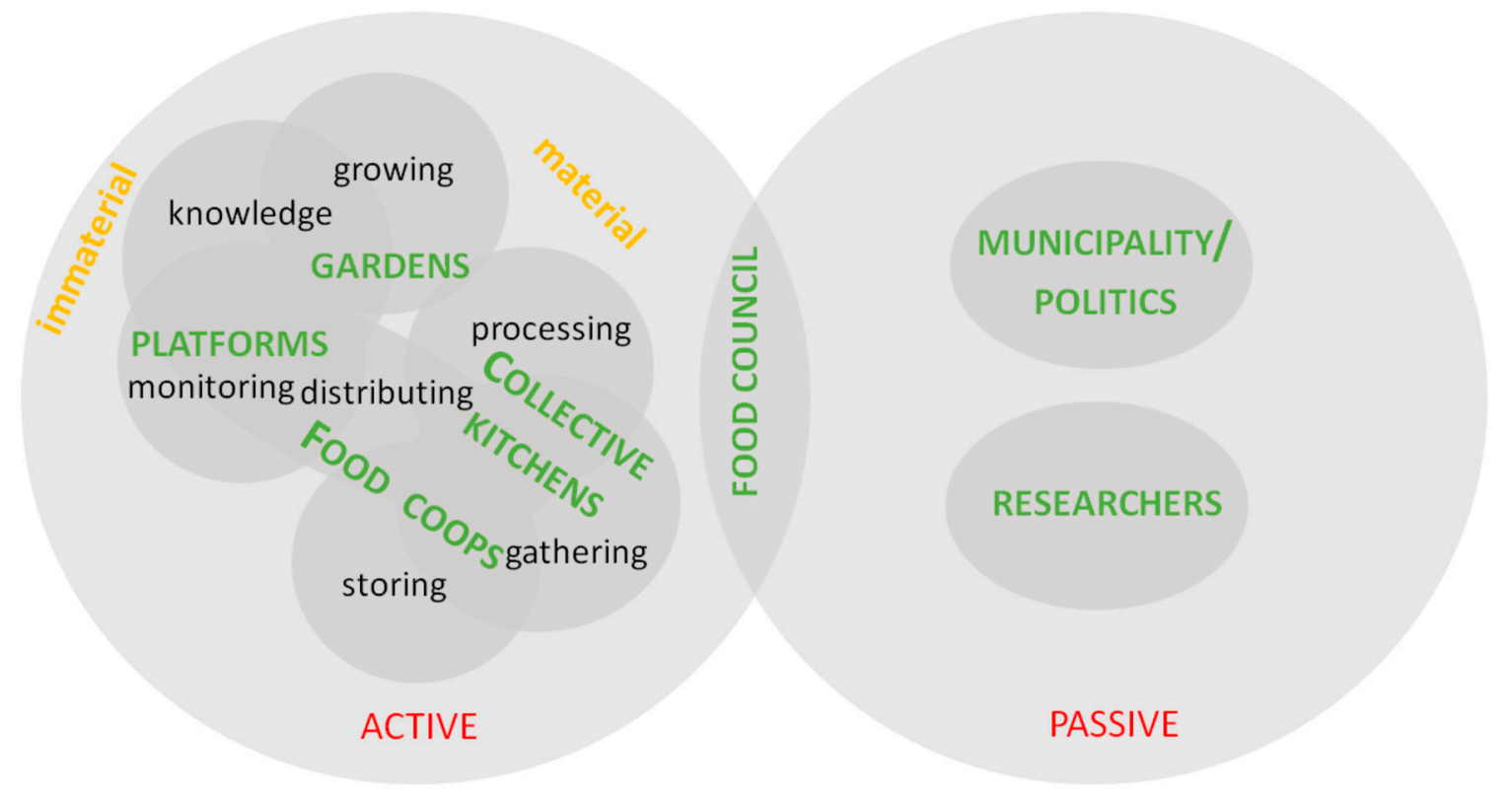

Figure 1. Selection of urban food commons actors by different attributes.

The first differentiation of the interviewees relates to an active or passive involvement of the actors. Aiming insights of many different perspectives, the label "actors of food commons" is not limited to actively involved commoners or the community, but also includes actors that have a strong professional connection to the commoners (i.e. passive actors within the city administration and 
researchers, see Figure 1). Actively involved actors are differentiated by more detailed attributes that describe their type of actions within the urban food system. Firstly, they govern either material (e.g., land and seeds to growth) or immaterial resources (e.g., knowledge on growing and processing techniques). Secondly, the resource can be handled differently: for example, food can be grown, distributed, stored, processed, gathered, or monitored. Knowledge about food can be generated and transported. Thus, urban food commons have different relations to the attributes growing, distributing, storing, processing, monitoring, and food gathering. We identified five different groups of active actors, each with different compositions of attributes: (i) the internet platforms (monitoring, knowledge, distributing; immaterial), (ii) the gardens (growing, material), (iii) the food coops (storing, distributing, gathering; material), (iv) the community kitchens (processing, distributing, gathering; material), and (v) the food council. The later is located in the intersection between actively and passively involved actors as the food council consists of actively involved people but also has an observing and mediatory role between commoners and in the city administration (Figure 1).

Each actor will open a singular perspective to broaden the scope of understanding the role of urban food commons and the urban food system. We are aware that the data obtained are influenced by the researcher's personal biases and idiosyncrasies, thus the responses of the interviewed actors were described in detail, separating these data from clustering and interpretation in the discussion section. Statistical analysis was not applied in this study.

We used "problem-centered interviews." This interview method is a theory-generating type of qualitative, semi-standardized, and guided interview that aims to increase the user's knowledge by an interplay between inductive and deductive thinking [21]. In general, qualitative interviews are widely used as a data collection tool in order to gather information about experiences, views, and beliefs of people involved in urban food commons. Thereby, the version of one-to-one interviewing has been identified as a valuable tool to provide information about the social milieu in which people exist and insight into people's attitudes, experiences, and perspectives [22]. Here, we developed an interview guideline (see Appendix A) concerning the present research questions that function as flexible thematic "cornerstones" that generate story-telling [23]. The structure of the interview guideline consists of three parts: (a) the introductory question that generates story-telling, (b) three narrative lead questions that aim at a successful response to the research questions, and (c) a final question that gives an opportunity to reflect, supplement, or relativize the statements. The order of the lead questions is interchangeable, aiming at the opportunity to react to the interview process flexibly, without drastically interrupting the respondent. It is also possible to leave out a lead question if the respondent already answered it during, e.g., the introductory question or another lead question [23]. The interviews were conducted in German.

The method of "qualitative content analysis" after Mayring [24,25] offers the possibility of classifying the results after categories are determined ex ante and derived from the research questions. Similar to the problem-centered approach of data collection, the categories are developed deductively. The category application that is defined in a coding agenda (Appendix A) works with prior formulated, theoretically derived aspects of analysis, bringing them in connection with the text. The three categories of analysis were value for sustainable urban development, relation to city administration/politics, and recommendations to enhance the potential and efficiency of urban food commons for urban transformation towards resilient cities.

In the discussion section, the most significant statements of the respondents are summarized by using abbreviations for each interviewee: F (Foodsharing), M (Mundraub), P (Peace of Land), FC (Food Coop), CK (Community Kitchen), FCB (Food Council Berlin), UR (Urban Research Group), ZR (ZALF), and GA (Grünflächenamt).

\section{Results}

The following sections summarize the contents of the nine problem-based in-depth interviews with experts related to urban food commons in Berlin, which are briefly described in the first 
paragraph of each section. Since the theoretical sampling of qualitative interviews is always linked to the respective setting, this rather novel topic does not allow for a larger number at the moment, and theoretical saturation was quickly reached. The interviews were conducted and analyzed with depth and openness.

\subsection{The Foodsharing Platform}

Foodsharing is an open online-platform where the self-organized community organizes the collection of food waste in different retail companies throughout Germany. The so-called ambassadors are representatives for a region or town that coordinate the collection in the involved businesses, give information to new "food savers," the persons who collect the food, and organize regular meetings. Since 2012, 100,000 voluntary food-savers have signed up to Foodsharing and have collected food from 42,000 food companies of all kinds.

There are positive effects for the development of a critical mass in cities and beyond: the communities consist of many people and therefore have a significant political importance and the power to "move something." These effects go beyond the aspect of nutrition; the community takes over tasks that normally are the state's responsibility, such as the reduction of food waste. Further, the societal framework is important. Spaces for discussion are created and people from different backgrounds come together and might inspire each other for a change of awareness. Here, the representative emphasizes the urban scale; in cities, the "power unfolds" because here social problems are taking place and the education level is higher.

There seems to be a certain business lobbyism with a resulting feeling of powerlessness in the citizens. People often do not have the capacity to organize things in another way, due to a lack of time and because they are "creatures of habit." Another problem exists in the political implementation. The implementation often fails in district offices, where a shortage of staff and young employees can be observed. Regulations are unadjusted and excessive, and, even though single persons support the initiatives, they often do not have any authority. Sometimes there might be an influential connection between single departments of city administration. Other Berlin districts might follow the prohibition or rules of the initiator district.

Communities have to demonstrate a critical mass, making clear that they are not single phenomena. Initiatives have to create a political importance with clear political demands. Therefore, a strong network is important, especially between the different initiatives. The sense of community has to be strengthened and people have to experience the power that a community can evolve. Within the groups, a process of democratization is important. Plenary sessions, clear structures, discussions, controversies, and elections are effective measures. Further, the establishment of an institution could build the bridge between initiatives, city administration, and politics.

\subsection{The Mundraub Platform}

Mundraub provides the largest open online-platform for the discovery and usage of edible landscapes and enables the community to map fruit trees and other edible plants in public spaces worldwide. Mundraub supports municipalities and other actors with the conception and implementation of edible cities/landscapes. Basically, Mundraub brings together fruit trees and people, making the food commons of public edible plants visible.

Edible plants in public spaces provide a low-threshold offer that is easily accessible and regardless of financial conditions of the people. It is more about educational than provisional factors-what is valuable about the platform. The direct experience of seasonality and a certain sensibilization for ecology increase the awareness of consumption patterns: recognizing what kind of fruits are growing at a certain time in the year makes clear that it is not natural to buy strawberries in the wintertime. The identification with urban spaces, the feeling of participation, the "long-term nature" of trees, and the cross-generational quality are other valuable factors. 
Sometimes there are invitations to conferences and cooperation, for example, regarding the smart city or edible city approach. Nevertheless, these efforts mostly seem to be because of the indirect impact of Mundraub's success: over the years, Mundraub has achieved a certain "branding" that is well-known throughout Germany. The main reason for collaborations is not the importance of the commons approach itself. In Berlin, the idea is recognized by the city, but initiatives are not invited to collective discussions. Fundamentally, in municipalities the implementation is not easy due to system pressures such as hierarchies and bureaucracy. Also within the administrations, the marketing of a concept is crucial. Concepts have to be promoted as positive for the city and have to be "sold" to the next higher level in the hierarchy (e.g., the mayor of a city). Another problem is the possible mistrust of the city administration towards the self-governance of initiatives. They want to "keep an eye" on the processes, because in the case of an initiative's dissolution, the city might keep the responsibility of the governed resources.

The development of clear responsibilities and rules regarding the "inheritance" and long-term care of resources within the initiatives is crucial. The consolidation and stabilization of projects combined with the establishment of a network could be the solution for a better collaboration with the city administration.

\subsection{The Peace of Land Urban Garden}

Since 2016, the self-governed community garden in the district of Prenzlauer Berg has provided space for workshops and other educational offers regarding (social) permaculture, community building and organization, architecture, self-sufficiency, and urban food production. Everybody is invited to join in courses or building actions, to grow food, or to implement their own projects in the garden. Further, Peace of Land is an official place of practice of the Institute for Permaculture e.V.

The garden is important as a field of experimentation, where visions and ideas are developed and directly implemented. Here, the main resources are experience, knowledge, and learning. Self-governance and self-organization create a high value: the participants become motivated, because needs and criticism are recognized and ideas can be implemented immediately. The non-hierarchical, participatory structure and the appreciation of needs strengthen the cohesion of the group, which leads to higher productivity. Food commons are also valuable in times of crisis. When the present infrastructure breaks down, commons initiatives can still supply food, because of their local field of action, short transport routes, and their knowledge about acting independently. Further, the garden provides a direct feeling of an "oasis" and nature in the middle of the city. It acts as an opposite to the alienation to nature, which also might have healing effects.

The representative of the garden never experiences any real obstruction by the city government, but there is little cooperation. Nevertheless, there is financial support, but more from the state than from the city. There is no debate about the whole approach of urban commons, but only about isolated phenomena, such as hygienic issues regarding food sharing. The problem is the severe demand for space in growing cities. It creates a challenge, because different demands have to be taken into account, such as employment and the economy. There are also different groups of interests, with concurrence between them. In food issues, large companies and industrial agriculture are more influential and sometimes hamper processes for their own good.

The mental resources and knowledge of the initiatives have to be used and recognized. Basically, it is important to find better solutions to integrate the requirements of the inhabitants. Here, these mental resources of initiatives are more valuable, because other instances such as consulting companies often do not reflect the reality. It is important to establish a network between the initiatives, both digital and personal.

\subsection{Food Coop Wedding-West}

In this 30-year-old food cooperative, decisions regarding production, distribution, and the type of food product are independently made by cooperative members. The products are obtained directly 
from the producers without a surcharge of the retail trade. The food is stored in self-organized rooms and distributed to members in accordance with certain rules. The community is responsible for orders, delivery, storage, and pricing. Decisions regarding the distribution of tasks, organization, storage spaces, suppliers, and so on are discussed in a monthly plenum.

The initiative is especially valuable for individual members. Initially taking part because of financial reasons, most people are becoming more conscious about sustainability and the impact of the own consumption. This is mainly happening through contact within the group via mail or while meeting in the storage room or the plenum. These contact platforms that all share enable the exchange of ideas and inspirations. The processes in the initiative are "close to the basis" and a kind of "workshop of ideas," where a mutual inspiration evolves. The storage room is also used for distributions and exchanges apart from the regular food-coop products: sometimes, members collect apples and bring it to the room, and other members produce jam from it and distribute it to the other members. Another important resource is the high amount of experience the community has with group processes and administrative structures as well as the positive effect-that people "know exactly" why they form a community regarding the same motivation-that all members have. The initiative has the potential to revive the district and to increase the identification with it.

There was never a cooperation between the food coop and the city administration. Rather, the feeling of resistance and being an "outcast" dominates and therefore the impression that they are not heard and recognized. The group struggles more with market dynamics. They have the problem of supply shortages, because more and more wholesale markets do not want to supply them. The reason for this is the small order of quantities and the customer change to, e.g., a bio-company. Another problem is in the lack of time capacity for most members, because many are "struggling for existence" and are "stuck in their work rhythm."

A support by the city would be crucial regarding the provision of rooms, the takeover of tasks, and the establishment of round tables between initiatives and city administration. Additionally, the access to subsidies should be easier, because the workload in voluntary positions is too high. Additionally, a contact person that bundles knowhow, facilitates the start of an initiative, and transmits that knowhow to others would be valuable. The transmission of know-how to starters by, e.g., a guideline has been evaluated as an important action. Networking is important to evolve the sense of community and thus to develop a common vision, more discussions, and more impact on the districts. The principle of food cooperatives should be normalized, without the unavoidable connection to resistance movements and critical consumerism. Right now, people do not see food as a commons: eating is "happening at home" and not outside, so far it is seen as a pure product that has to be bought. Fundamentally, food should be accessible to everyone.

\subsection{The Baumhaus Community Kitchen}

Baumhaus is an open socio-cultural, self-organized initiative "grown out of the neighborhood." The initiative is a growing community, building project, and event space that supports and hosts different social and ecological projects in their rooms. One of the projects is a weekly community kitchen, where dinners are cooked from food waste and distributed to the community for donation. Further, Baumhaus provides storage space for a food cooperative and a community-supported agriculture.

There is a strong gathering effect of food and eating: people come together and are connected. In short, cooking and eating "is the easiest practical action you can do together," and the access is easy with different (linguistic) backgrounds. Another positive effect has the direct connection to food waste: people see the amount of food and enjoy the resulting dinner, which strengthens the awareness of societal consumption patterns in a pleasant way. It becomes clear that people have to connect to change something. It is more suitable to talk about common sense instead of commons, because it is more about the feeling that the community has to do and create something together. 
Some municipal effort can be observed. For example, recently 1 million euros was provided for measures towards zero waste, including food waste. Further, the recommendations and strategies provided by the Food Council are recognized by the city, but still the question arises whether they are ultimately implemented.

The scale of initiatives worked on is so far too small. The question about the next step arises: maintaining the voluntariness of the work is not expedient for the continuance of the initiatives. The commoners have to professionalize their work and seek new strategies, especially regarding financing and impact. The perspective should expand to a transformation of the neighborhood as a common objective of a network. It is not enough to gather for countless network meetings; it is important to focus on a common objective (such as transformation) and locate oneself in the whole process. The network has to define a political demand and become visible. Further, the initiatives have to consider how they can help and support each other: the support of newly founded projects, the transfer of tools and knowledge about grant applications, and group organization and project management might be suitable. Berlin needs more counseling centers regarding possible financial support: commoners have to spend excessive amounts of time applying for grants while the workload of their voluntary effort is already high.

\subsection{The Food Council of Berlin}

The Food Council of Berlin is a civic-society institution, consisting of different actors that are committed to ecological, sustainable, and equitable food production and distribution in the area of Berlin. Since 2016, the Food Council has officially represented positions and claims for a viable and sustainable nutrition system, aiming at a political value of the topic. The political demands are mostly sent to the Senate of Berlin and the regional politics of Brandenburg. The elected group of voluntary spokesmen consists of 12 persons. The representative is a good example for the simultaneous perspective of an actively and passively involved food commons actor. As a member of the Food Council, the representative occupies a mediatory and advisory role; at the same time, he works as a hygiene and education officer at the Berliner Tafel e.V., a charitable organization that redistributes food waste to homeless persons and other people in need. Therefore, the Food Council also has a substantially active role in the work and processes of food-related initiatives.

A positive trend of people who want to participate in processes is evolving. That is a sign for an increasing interest in the matters people have to deal with. It is important to see food as a commons, especially because food occupies a crucial role in the connection of human beings. Everybody is connected through food, and as it is food can be seen as a commons in light of its natural background. The value of food commons is found especially in the terminology. It can be useful for synergy effects and the compiling of resources in Berlin. Due to a collective term such as food commons, it is becoming clear that all are working on the same project. There might be many resources in Berlin, but often actors do not know about other actors. There might be no guarantee that the pure existence of a term is sufficient to connect these actors, but there are parallels between them. This is especially important for existing initiatives, because it is always crucial to have a tool to enthuse people to become actively involved in edible city initiatives.

There is little cooperation between different actors, which might only be improved by a visible connection between them or by "sitting on one table". Nevertheless, some initiatives collaborate, even though it can be observed that initiatives sometimes work against each other. The Food Council highlights a positive development regarding Berlin's efforts. For example, the coalition agreement of the new city government enables the provision of money for food issues. Additionally, new strategies include the "nutrition strategy" in process and the position paper of the Food Council brought to the government. Nevertheless, there are gaps in the implementation of such good intentions. For example, there are different departments that are responsible for food issues. There is not one pooled responsibility; nutrition affects different political actors, such as the office for consumer protection, the District Department of Parks and Green Areas, and the Senator for Construction. 
At the same time, collaboration between the departments is insufficient, and often only an actor's own interests are prioritized and pursued. These encrusted structures entail competence conflicts, inconsistency, and a lack of a central contact person for nutrition issues. Additionally, ideas and agendas are sometimes overturned because of the subjective decision of single persons. Another problem is that officials often state that they "are already getting things done, why should we do more?" This often has a thwarting effect on the efforts of commoners. This effect also means that there is no guarantee that strategies and ideas will ultimately be implemented. The "real" experts are the commoners or initiatives, but implementation is done by a group that is put together by the city government.

For a better implementation, the visibility of the connection between the actors by developing a network between initiatives is a crucial point. Additionally, there should be a cross section and coordination point that implements these networking efforts. This central coordination point must not be tied to a government or senator but should function as its own office that outlasts different governmental periods. The coordination point should also include a contact person that all interested persons can ask. If somebody wants to become active, it is important that he/she is "getting there fast." Therefore, the central contact person could transfer the people to initiatives of their interest and show the different possibilities. Here again, a strong network would be helpful. A significant problem is the principally voluntary nature and the high workload of the people who are active in an initiative. Here, the representative recommends that the government has to disburden the initiatives by providing money, for example, for the payment of the mentioned contact person and by loosening barriers such as grant applications. Further, the representative highlights the importance of clear guidelines and rules, especially regarding food (e.g., hygiene issues).

\subsection{The Urban Research Group}

This interviewee is an urban researcher, consultant, and expert on integrated post-industrial urban development, specifically culture and creative industries, real estate market dynamics, intermediate and adaptive reuse of vacant buildings, bottom-up urban development, and urban commons. The Urban Research Group is a self-organized collective of five doctoral and postdoctoral researchers from different backgrounds with current research foci on urban commons and new developments in critical urban studies.

A commons can be seen as radical, but not in the sense of radicalism but in relation to the origin of the term. Radical comes from the Latin term "radix," which means root-a quite suitable metaphor to the bottom-up processes steering urban commons. The current urban commons research has dedicated the most attention to these processes and mostly examines political questions from an activists' perspective. So far, no attention has been paid to sustainable urban development in urban commons research. Four levels of sustainability—ecological, economic, social, and cultural—can be described to identify the role of urban commons in this debate. Natural resources are the "birthplace" of commons, so commons are often linked to a left-ecological ethic: the initiatives are mainly involved unsustainable/ecological efforts such as resource saving mobility, access to water, and alternative energy. On the economic level, urban commons play a substantial role, because there is an increasing instability due to the high competition for land. Especially in Berlin, rentals are designed and directed by market, even though it would be feasible to steer prices in favor of the citizens. On the social level, urban commons have a high value. They create cooperative opportunities for participation. Further, urban commons are not profit-oriented and are therefore accessible to different groups, regardless of their (financial) background. Nevertheless, a certain homogeneity in the level of education can be observed. On the cultural level especially, the indirect value of urban commons is important. The transfer of commons to food issues is appropriate. Food commons can be important for resilience, especially social resilience and the prevention of "food deserts." Additionally, the local scale and ideas of sufficiency play a substantial role in urban commons initiatives, which is quite valuable for sustainable food systems. Further, commons change the "customer-provider" relations of a society. 
Food commons do not play a substantial role in German politics. In Germany, much relies on the land use plan, which is problematic because there is a high competition for land and there is no space included for, e.g., urban gardening or other space-related urban commons. Moreover, in Berlin, few debates about urban commons have evolved. The interviewee mentioned a long period of time during which problems such as a lack of money and social problems have dominated in Berlin. There were limited possibilities to integrate "luxury" issues such as urban commons. Still, there is little cooperation between commoners and the municipality, except in the field of housing politics, e.g., co-housing. Here, the city is obliged to cooperate due to provision shortages of living space.

The interviewee recommends the avoidance of "commons washing." The application of this term often dilutes the fact that not the entirety of a city can be a commons, but all takes place on the scale of individual projects. Apart from terminology issues, the existing network and connections between the initiatives are important. Thus, like-minded people become connected, a certain political power evolves and the exchange of know-how is initiated. Further, responsibilities and tasks should be transferred to the city administration, e.g., in the form of "commons hybrids," because the time consumption of activism seems to be a significant problem. Here, the risk of handing over power to the government exists, but it might be the only way for commons to avoid remaining a "fringe phenomenon."

\subsection{The Leibniz Centre for Agricultural Landscape Research (ZALF)}

This interviewee is a researcher at the Leibniz Centre for Agricultural Landscape Research and works on the analysis and sustainability impact assessment of food systems and of alternative food networks and short food supply chains.

Commons support the ability for self-empowerment and initiate the engagement of the citizens. Problems can be solved on a local scale and at the same time, the awareness of the impacts on a global scale can be developed. Commons initiatives can be seen as a testing ground for sustainable practices where good methods and opportunities are demonstrated. Especially regarding food, there are many opportunities to integrate sustainable practices, for example, in production, transport, and land management. On the social scale, normally a dualism between state and private sector dominates, while commons demonstrate a third option. Conditions of the present society are reversed: consumers transform into so-called "prosumers." Nevertheless, the representative states that food commons might not be a real commons, because it has a high relation to the spatial scale, and urban spaces are in most cases not commons. Additionally, the interviewee identifies a lack of a link to the approach of food sovereignty, which in her opinion is crucial for future food systems.

There is little cooperation between initiatives and city administration, except for the field of urban gardening. The city at least intends to establish an official contact person for the projects, but in general the principle of commons is not well-known and not part of the political debate. Nevertheless, other institutions such as neighborhood management offices now provide money. There is a strong space reliance of food production. The competition for land is severe, and investors are currently in a more powerful position. Further, implementation is difficult because of the two governmental levels of federal province and district administration in Berlin that must be balanced.

It is fundamentally important to create a critical mass. The problem here is that the actors are dispersed and that most do not identify themselves as a part of a network. Therefore, it is crucial to become visible as a network. At the same time, the city administration and politics must recognize the value of initiatives and take participatory measures, such as initiating a forum or platform. For better implementation, it is also important to provide room and space for the projects, despite the fact that this may be difficult because of the competition for land.

\subsection{Grünflächenamt}

This interviewee is head of project development and citizen participation in one of Berlin's District Departments of Parks and Green Areas (Grünflächenamt). This department attends structural and 
horticultural issues of public green spaces and parks. Other tasks are the control and maintenance of park and street trees, the cleansing of public facilities, and the supervision of allotment gardens. Especially for space-related food commons such as urban gardens or fruit trees, the department is an important reference.

The interviewee especially emphasizes the positive value of fruit trees, because they are accessible to everyone and not a private property. Further, they increase the sensibilization and public awareness for domestic trees.

There are severe structural problems on the administrative and political level. Currently, politicians intensively claim more efforts regarding the approach of edible cities, such as more gardens and more networking. Simultaneously, the political side does not provide money for new resources in the city administration with resulting staff shortages and insufficient implementation of the demands. The problem is intensified by the fact that there is no distinct office or department for food issues and the different departments prioritize their core tasks. Approval processes for more resources and staff are long-lasting and static, due also to regulations for public service, which is compulsory for all employees. This fact makes flexible, fast, and short-term employment or the creation of flexible project teams nearly impossible. Every job must have a fixed title and must be a permanent position financed by taxes; therefore, decision-makers need to carefully weigh each choice surrounding recruitment. Another problem is the huge pressure on spaces. In this context, many see public green spaces as the "universal remedy" for the establishing of initiatives. It is important to look for other spaces, such as roof tops. Public green spaces have to satisfy the needs of many different user groups such as those for sports and recreation. Therefore, it is problematic to "reserve" these spaces for, e.g., gardens. The interviewee has experience indicating that gardens are often affected by vandalism and that fences and other restrictions are therefore nearly unavoidable. In turn, this leads to an exclusion of other user groups, causing a dilemma for the Parks and Green Areas Department, which has the task of preserving publicity.

The interviewee urgently recommends facilitating new jobs in city administration and a coordination office between policy and administration. This contact person should have certain features: he/she must be well informed in all related areas with knowledge about the districts and their structures whilst being capable of realistic estimates of what is feasible and maintaining a neutral opinion that leaves space for all actors. Further, there is a need for an establishment of flexible short-term project groups that are not in the public service. Furthermore, other spaces should be considered. Here, old cemeteries or allotment gardens are suitable because of the low soil contamination. More capacities and (financial) resources provide urban reconstructing or redevelopment areas. Here, more funds and advisory councils for reconstructing as well as neighborhood offices exist. Basically, everything must happen on the political level. Politicians have the power to bring together all actors and to compose their own project groups that consist of existing staff. Nevertheless, it always depends on one's priorities. At the moment, food seems not to be a political focus.

\section{Discussion}

An urban food commons and its impact on sustainable urban futures are not currently a research focus, although our interviews clearly highlight the commitment of relevant actors to co-develop more resilient cities. Urban commons bear the potential towards participatory, democratic, community-building, and bottom-up processes that re-situate citizens as key actors of future cities $[2,3,16]$. Urban transformation implies a systemic, long-term, and vision-led change towards sustainability in cities [26]. Here, special efforts towards resilience, social interaction, and collective decision making are identified as key factors co-shaping urban transformation $[27,28]$. The results of the interviews reflect multilayered potentials that urban food commons bear regarding a viable urban transformation. 
Regarding the positive value of food commons for a sustainable urban development in Berlin, several statements that have a clear connection to the urban transformation approach recurred in the interviews. The creation of spaces and platforms for the exchange of ideas and goods, high accessibility, regardless of linguistic, generational, or cultural backgrounds, the increase of identification within the neighborhood, the positive impacts of group cohesion and connections between people, and its value as a testing ground for sustainable practices and the local field of action were emphasized by many respondents. Especially the advancement of participation, motivation, and self-empowerment and the increase of consciousness and sensitization towards a more sustainable lifestyle, a global impact, and local food production were often mentioned.

Many statements implied driving features for the inclusive co-creational empowerment of citizens. Urban commons provide easy and inclusive access to non-profit, non-hierarchical, and co-created spaces regardless of cultural, generational, linguistic, or financial background (highlighted by F, M, P, FC, CK, and UR). Urban commons facilitate self-organization, self-empowerment, and a takeover of responsibilities by citizens at a local level (F, M, P, CK, and ZR).

Urban food commons demonstrate gathering effects, strengthen local identity and cohesion, and thus revive neighborhoods. Food is widely recognized as an important connection between human beings (F, M, P, FC, and FCB).

Urban commons raise awareness for a need of transformation towards future proofed cities and food systems by the development of a critical mass (F and CK). Often mentioned were the educational value, the shared knowledge of group processes and administrative structures, the consumption pattern (esp. the food waste practices), the seasonality of food production, and the enhanced detachment from nature (M, P, FC, and CK). Moreover, sensibilization regarding domestic trees (GA), knowledge of solutions on a local level, and the transformation of consumers to "prosumers" were highlighted (ZR). Thus, unisono "Commons" are attributed as a chance for the acceleration of urban transformation towards sustainability (i.e. "common sense \& motivation" instead of commons; FC and CK). Commons are often linked to a left-ecological ethic and are deemed as per se sustainable (UR) and valuable in times of crisis $(\mathrm{P})$. Urban commons provide a testing ground for sustainable practices and demonstrate opportunities and a "third way" of dualism between state and private sector (ZR). Urban commons are seen as a counter-model to increasing instability due to competition for land and the directions of the market (UR). Food commons could be a link to food sovereignty (ZR) and thus important for urban resilience (UR). The term "food commons" can be useful for synergy effects and the bundling of resources by showing parallels between actors (FCB), work at local levels (UR), and easy access to a commons such as fruit trees (GA).

Regarding the relation of urban food commons to the current practice of city administration and politics in Berlin, respondents mentioned repeatedly their absence in official politics ( $P, Z R$, and UR) and the feeling of powerlessness and being "outcast" (F and FC). Severe structural problems lead to the perception of being lost in public administration: lacking cooperation between initiatives and municipality (P, FC, FCB, and ZR), mistrust of administration towards self-governance, long-lasting and static processes, competence conflicts and insufficient collaboration between departments, and a lack of a central contact for food issues (M, GA, and FCB). The shortage of (young) staff in city administration (F, GA, and M) was mentioned as a problem. The implementation problems are related to highly diverse governmental levels that have to be involved (i.e. city, district, and neighborhood; $\mathrm{ZR})$, to unadjusted and excessive regulations (F), and to problematic regulations for public service that make flexible, fast, and short-term employment and flexible project teams nearly impossible (GA). A viable implementation of new approaches such as the edible city or urban food commons is difficult in Berlin. Further, the high demand for space causes severe competition for land with a simultaneously powerful position of investors (ZR). Additionally, public spaces have many user groups that make it difficult to "reserve" spaces for food issues due to a risk of exclusion of other groups (GA). Another barrier is a lack of participant's (time) capacity (F and FC). The mostly voluntary nature of the participants' involvement often threatens the further existence of initiatives. 
The respondents had versatile recommendations for a better integration and implementation of urban food commons in Berlin. Above all, urban commons have to enhance their ability for setting the political agenda: the creation and demonstration of a critical mass (F, ZR) by building up a visible, open, local network to connect like-minded people, to evolve political power, to exchange know-how, and to support the creation of common visions and discussions as well as a sense of community towards transformation (F, M, FC, CK, FCB, ZR, and UR). Another crucial measure is the bridge between actors, especially between initiatives, city politics, and administration. This cross section, mediation and coordination point should have a direct contact person for all involved actors (GA) with independency from governmental periods (FCB) that also supports networking efforts such as open access round tables (FC and FCB). Additionally, there is a high demand for new job positions in city administration and flexible short-term project groups aside from public service (GA) and a provision of resources such as space and rooms by the city (FC, P, ZR, and GA). Further, the respondents recommend a consolidation, stabilization, and professionalization of projects, clear guidelines, and rules (i.e., a guideline for starters; FC, CK, FCB, and M) and the transfer of responsibilities and tasks to the city due to the high time consumption of activism (UR). At last, there should be easier access to subsidies, grants, and resources to disburden a high voluntary workload of initiatives by, e.g., providing more counseling centers regarding financial support and grant applications (FC, CK, and FCB).

The edible city approach has a strong reliance on the commons approach and will foster the agenda setting for an urban food commons. It is an urban form of traditional commons-natural common goods that are accessible to everyone but with the same social potentials of new commons such as increases in identification, consciousness, and participation. So far, the edible city approach is focused on "natural food commons," such as fruit trees and gardens, in order to increase the people's self-reliance. Other food commons also have to be integrated in this perspective. By connecting the different producing, storing, and processing initiatives in a network, new value chains become visible (Figure 2). For example, the location of fruit trees is visualized by platforms such as Mundraub; citizens pick them and bring them to existing storage rooms of food coops. From there, the fruits can be distributed in the neighborhood or even processed in a community kitchen such as Baumhaus. Many of these value chains can be initiated and supported by an efficient edible city network within a city and among cities worldwide.

Nevertheless, these networking efforts cannot be performed by the initiatives alone, because actively involved people are already confronted with a high voluntary workload. For this reason, it is necessary to provide the services associated with urban commons with public funding. The staff can be pooled in one central point for food issues in the intersection between initiatives and city administration. It is both integrated in the initiatives' processes and has a powerful and independent position within city administration. This mediation and coordination point mediates, informs, transmits, connects, consults, and engages in public relations for the network and can facilitate close collaboration with bottom-up organizations such as the food council. The strategies conceived by the network have to be addressed properly by city administration and politics (Figure 2). 


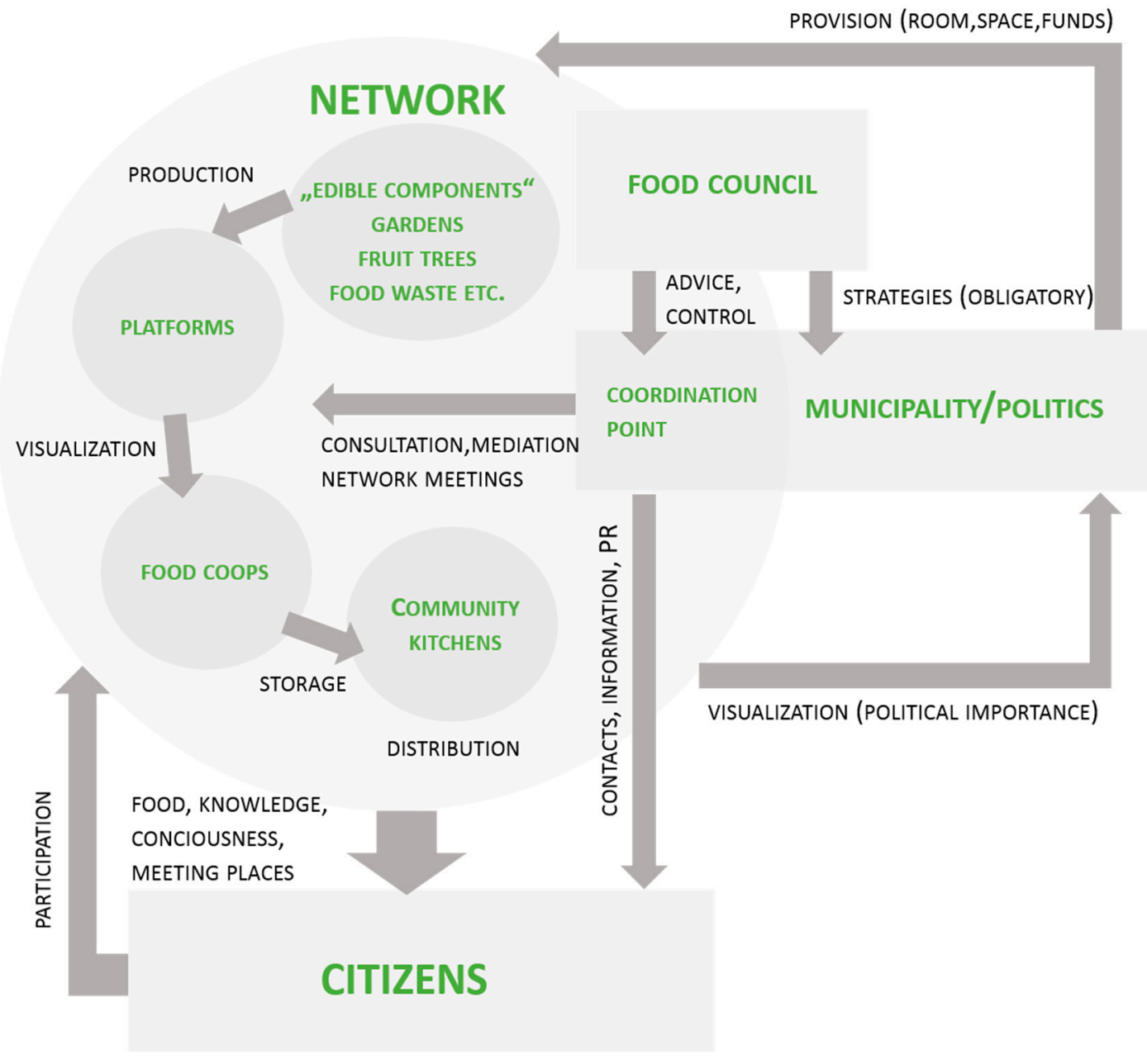

Figure 2. Relations between different actors in an edible city network.

\section{Conclusions}

Urban commons in Berlin have the potential to be key players in the transition towards a sustainable city that strengthens identification, participation, self-organization, and social resilience, steered by bottom-up processes. Nevertheless, the approach is widely ignored by city officials and in commons research, and the link between commons and sustainable urban development remains unexplored. The commons approach opens up new perspectives and visualizes connections between actors. For sustainable food systems of the future, the transfer of commons principles to food provision and production has substantial economic potential. Food commons will be an effective supplier due to their local field of action, knowledge, and independency from the state and the market. At present, the viable political integration of existing initiatives is lacking due to many structural implementation problems.

Author Contributions: Conceptualization, N.S., I.S., T.W., and S.E.R.; methodology, N.S.; validation, N.S., I.S., T.W., and S.E.R.; formal analysis, N.S.; investigation, N.S.; writing-original draft preparation, N.S.; writing-review and editing, I.S., T.W., and S.E.R.; visualization, N.S. and I.S.; funding acquisition and supervision, I.S., T.W., and S.E.R.

Funding: This research received funding from the Bundesministerium für Bildung und Forschung (Grant number 01UH1606A) and from the European Commission (Grant number 776665).

Acknowledgments: We thank all representatives involved in the interviewees, valuable insights, and fruitful discussions on urban food commons. We thank the three anonymous reviewers for helpful comments and suggestions to improve this manuscript and Peter Holm for editing comments. 
Conflicts of Interest: The authors declare no conflict of interest. The funders had no role in the design of the study; in the collection, analyses, or interpretation of data; in the writing of the manuscript; or in the decision to publish the results.

\section{Appendix A}

Table A1. Interview guideline.

\begin{tabular}{|c|c|}
\hline Stage & Question \\
\hline Introducing Question & Do you see yourself as an actor of sustainable urban development? \\
\hline Leading Questions & $\begin{array}{l}\text { Do you think it is reasonable to define food as a commons? } \\
\text { Is there an existing political debate about (food) commons? } \\
\text { Has there been collaboration or cooperation with the city } \\
\text { administration/politics so far? Or do you rather perceive a } \\
\text { certain obstruction? } \\
\text { How could food commons become better integrated in a sustainable } \\
\text { urban development in the future? }\end{array}$ \\
\hline Final Question & Do you have any further comments? \\
\hline
\end{tabular}

Table A2. Coding agenda.

\begin{tabular}{|c|c|c|c|}
\hline Category & Definition & Examples & Coding Rules \\
\hline $\begin{array}{l}\text { C1: Value for sustainable } \\
\text { city development }\end{array}$ & $\begin{array}{l}\text { Valuable characteristics } \\
\text { of food commons that } \\
\text { have the potential to } \\
\text { support a transformation } \\
\text { towards sustainable } \\
\text { cities }\end{array}$ & $\begin{array}{l}\text { With cooking, it is easy } \\
\text { to do something good; it } \\
\text { is the easiest practical } \\
\text { action you can do, } \\
\text { everybody can do } \\
\text { something; also with } \\
\text { different backgrounds, } \\
\text { there is a low inhibition }\end{array}$ & $\begin{array}{l}\mathrm{C} 1 \text { mainly aims to } \\
\text { extract positive values, } \\
\text { but also negative aspects } \\
\text { are included; if negative } \\
\text { aspect is external or } \\
\text { implementation } \\
\text { problem } \rightarrow \text { C2 }\end{array}$ \\
\hline $\begin{array}{l}\text { C2: Relation to city } \\
\text { politics }\end{array}$ & $\begin{array}{l}\text { Relation to current city } \\
\text { administration/politics } \\
\text { in Berlin and other } \\
\text { implementation } \\
\text { problems for an } \\
\text { integration of food } \\
\text { commons }\end{array}$ & $\begin{array}{l}\text { The problem is that } \\
\text { different departments } \\
\text { are responsible for the } \\
\text { topic of food and that } \\
\text { there is no pooled } \\
\text { responsibility }\end{array}$ & $\begin{array}{l}\text { Positive and negative } \\
\text { relations regarding } \\
\text { cooperation and } \\
\text { recognition between } \\
\text { initiatives and city; other } \\
\text { implementation } \\
\text { problems are also } \\
\text { included }\end{array}$ \\
\hline C3: Recommendations & $\begin{array}{l}\text { Recommendations } \\
\text { regarding a better } \\
\text { political and internal } \\
\text { implementation of food } \\
\text { commons }\end{array}$ & $\begin{array}{l}\text { A central coordination } \\
\text { point that is available to } \\
\text { everybody that wants to } \\
\text { become active in } \\
\text { initiatives; if somebody } \\
\text { wants to become active, } \\
\text { it is important that } \\
\text { he/she can quickly do so }\end{array}$ & $\begin{array}{l}\text { Recommendations for } \\
\text { both policy and internal } \\
\text { processes within } \\
\text { initiatives are included }\end{array}$ \\
\hline
\end{tabular}

\section{References}

1. Moglia, M.; Cork, S.J.; Boschetti, F.; Cook, S.; Bohensky, E.; Muster, T.; Page, D. Urban transformation stories for the 21st century: Insights from strategic conversations. Glob. Environ. Chang. 2018, 50, 222-237. [CrossRef]

2. Gorenflo, N. Introduction. In Sharing Cities-Activating the Urban Commons; Shareable: Mountain View, CA, USA, 2017; pp. 20-35.

3. Dellenbaugh, M.; Schwegmann, M. Actors of Urban Change from an Urban Commons Perspective. Urban Commons. In Actors of Urban Change Newspaper; Robert Bosch Stiftung GmbH: Stuttgart, Germany, 2017; Volume 3, pp. 15-17. 
4. Theaker, I.G.; Cole, R.C. The role of local governments in fostering "green" buildings: A case study. Build. Res. Inf. 2001, 29, 394-408. [CrossRef]

5. Rode, P.; Burdett, R. Cities: Investing in energy and resource efficiency. In Towards a Green Economy: Pathways to Sustainable Development and Poverty Eradication; UNEP: Cambridge, UK, 2011; pp. 453-492.

6. Zhang, X.; Bayulken, B.; Skitmore, M.; Lu, W.; Huisingh, D. Sustainable urban transformations towards smarter, healthier cities: Theories, agendas and pathways. J. Clean. Prod. 2018, 173, 1-10. [CrossRef]

7. Kratzwald, B. Urban Commons-Dissident Practices in Emacipatory Spaces. In Urban Commons: Moving Beyond State and Market; Dellenbaugh, M., Kip, M., Bieniok, M., Müller, A.K., Schwegmann, M., Eds.; Birkhäuser: Basel, Switzerland, 2015; pp. 26-42.

8. Bollier, D. The Commons: A Neglected Sector of Wealth-Creation; Heinrich-Böll-Stiftung: Berlin, Germany, 2010. Available online: http://www.hebrewcollege.edu/sites/default/files/Sova_World\%20Belong\% 20Commons.pdf (accessed on 24 September 2018).

9. Kip, M. Moving Beyond the City: Conceptualizing Urban Commons from a Critical Urban Studies Perspective. In Urban Commons: Moving Beyond State and Market; Dellenbaugh, M., Kip, M., Bieniok, M., Müller, A.K., Schwegmann, M., Eds.; Birkhäuser: Basel, Switzerland, 2015; pp. 42-60.

10. Bauwens, M.; Vasilis, N. Changing Societies through Urban Commons Transitions; P2P Foundation: Amsterdam, The Netherlands, 2017. Available online: https://www.boell.de/sites/default/files/changing_societies_ through_urban_commons_transitions.pdf (accessed on 15 December 2018).

11. Bieniok, M. The Complexity of Urban Commoning from a Psychological Perspective. In Urban Commons: Moving Beyond State and Market; Dellenbaugh, M., Kip, M., Bieniok, M., Müller, A.K., Schwegmann, M., Eds.; Birkhäuser: Basel, Switzerland, 2015; pp. 60-72.

12. Foster, S.; Iaione, C. Ostrom in the City: Design Principles for the Urban Commons; The Nature of Cities, 2017. Available online: https:/ /www.thenatureofcities.com/2017/08/20/ostrom-city-design-principles-urbancommons / (accessed on 26 September 2018).

13. Commons Network. Available online: http://www.commonsnetwork.org/ (accessed on 20 September 2018).

14. Commons Institute. Commons Entstehen Durch Commoning. Available online: https://commons-institut. org/ (accessed on 20 September 2018).

15. Borch, C.; Kornberger, M. Urban Commons. Rethinking the City; Routlege: New York, NY, USA, 2015.

16. Ferguson, F. Make_Shift City. Renegotiating the Urban Commons; JOVIS Verlag: Basel, Switzerland, 2014.

17. Euler, J. Conceptualizing the Commons: Moving Beyond the Goods-based Definition by Introducing the Social Practices of Commoning as Vital Determinant. Ecol. Econ. 2018, 143, 10-16. [CrossRef]

18. Wiskerke, J.S.C.; Viljoen, A. Sustainable food planning: Evolving Theory and Practice; Wageningen Academic Publishers: Wageningen, The Netherlands, 2012.

19. Goldstein, B. Assessing the Edible City. Environmental Implications of Urban Agriculture in the Northeast United States. Ph.D. Thesis, Technical University of Denmark, Lyngby, Denmark, 2017. Available online: http:/ / orbit.dtu.dk/files/137624163/BGoldstein_dissertation_final.pdf (accessed on 12 February 2018).

20. Säumel, I.; Reddy, S.E.; Wachtel, T. Edible City solutions-One step further to foster social resilience through enhanced socio-cultural ecosystem services in cities. Sustainability. in press.

21. Witzel, A. The Problem-Centred Interview. In Forum Qualitative Social Research; Freie Universität Berlin: Berlin, Deutschland, 2000; Volume 1. Available online: http:/ / www.qualitative-research.net/index.php/ fqs/article/view/1132/ (accessed on 11 May 2018).

22. Ryan, F.; Coughlan, M.; Cronin, P. Interviewing in qualitative research: The one-to-one interview. Int. J. Ther. Rehabil. 2009, 16, 309-314. [CrossRef]

23. Nohl, A.M. Interview und Dokumentarische Methode; Springer Fachmedien Wiesbaden: Wiesbaden, Germany, 2017.

24. Mayring, P. Qualitative Content Analysis. In Forum Qualitative Sozialforschung/Forum: Qualitative Social Research; No 2 Qualitative Methods in Various Disciplines I: Psychology; Freie Universität Berlin: Berlin, Deutschland, 2000; Volume 1.

25. Mayring, P. Qualitative Content Analysis: Theoretical Foundation, Basic Procedures and Software Solution. Edited by SSOAR. 2014. Available online: https:/ / www.ssoar.info/ssoar/bitstream/handle/document/39517/ ssoar-2014-mayring-Qualitative_content_analysis_theoretical_foundation.pdf (accessed on 11 June 2018). 
26. Ernst, L.; de Graaf-Van Dinther, R.E.; Peek, G.J.; Loorbach, D.A. Sustainable urban transformation and sustainability transitions; conceptual framework and case study. J. Clean. Prod. 2016, 112, 2988-2999. [CrossRef]

27. Folke, C. Resilience: The emergence of a perspective for social-ecological systems analyses. Glob. Environ. Chang. 2006, 16, 253-267. [CrossRef]

28. Wolfram, M.; Frantzeskaki, N.; Maschmeyer, S. Cities, systems and sustainability: Status and perspectives of research on urban transformations. Curr. Opin. Environ. Sustain. 2016, 22, 18-25. [CrossRef]

(C) 2019 by the authors. Licensee MDPI, Basel, Switzerland. This article is an open access article distributed under the terms and conditions of the Creative Commons Attribution (CC BY) license (http:/ / creativecommons.org/licenses/by/4.0/). 